Trinity University

Digital Commons @ Trinity

Political Science Faculty Research

Political Science Department

$10-2016$

\title{
Partisanship by Invitation: Immigrants Respond to Political Campaigns
}

James A. McCann

Katsuo A. Nishikawa Chávez

Trinity University, knishika@trinity.edu

Follow this and additional works at: https://digitalcommons.trinity.edu/polysci_faculty

Part of the Political Science Commons

\section{Repository Citation}

McCann, J.A., \& Nishikawa Chávez, K.A. (2016). Partisanship by invitation: Immigrants respond to political campaigns. The Journal of Politics, 78(4), 1196-1210. doi: 10.1086/686688

This Article is brought to you for free and open access by the Political Science Department at Digital Commons @ Trinity. It has been accepted for inclusion in Political Science Faculty Research by an authorized administrator of Digital Commons @ Trinity. For more information, please contact jcostanz@trinity.edu. 


\title{
Partisanship by Invitation: Immigrants Respond to Political Campaigns
}

\author{
James A. McCann, Purdue University \\ Katsuo A. Nishikawa Chávez, Trinity University
}

\begin{abstract}
As the size of the foreign-born population in the United States has climbed, political scientists have focused increasing attention on immigrant incorporation into American politics. Much previous work emphasizes the impediments to partisan incorporation for the foreign-born. Drawing from two-wave panel surveys of Mexican immigrants administered during the national elections of 2006 and 2008, we show that levels of partisanship for this population rise markedly in campaign environments. These shifts are largely in a Democratic direction. An experiment embedded in the 2008 survey demonstrates that immigrants are highly sensitive to political appeals extended by the Democratic side and modest amounts of exposure to political advertisements can have sizable long-term effects on party identification. These findings suggest that while the foreign-born may never possess the kinds of stable partisan orientations that are characteristic of native-born Americans, they are no strangers to party politics.
\end{abstract}

$\mathrm{O}$ ne of the most striking features of life in the United States in the twenty-first century is the growing ethnic diversity in all parts of the country, a phenomenon that is due in large part to a rapid rise in migrant settlement from abroad. At present, some 42 million people in the United States are foreign-born, or approximately one-eighth of the total population. The vast majority of immigrants are of Latin American or Asian origin. By contrast, in the early 1970s, only about 1 in 20 residents was an immigrant. This substantial growth in the foreign-born population has sparked much interest among political scientists in the social, economic, motivational, administrative, and political factors that encourage or impede immigrant incorporation into American democracy. Much of this work examines formal indicators of democratic expression and inclusion, such as acquiring citizenship rights through naturalization, participating in elections, involvement in community groups, signing petitions, or making donations to political causes (e.g., Barreto
2005; Kam, Zechmeister, and Wilking 2008; Pantoja, Ramirez, and Segura 2001; Ramakrishnan 2005; Verba, Schlozman, and Brady 1995). In this article, we focus on an equally important but informal marker of political incorporation, self-described membership in a major party.

For generations, the Democratic and Republican parties have served as the principal foundations of American political and civic life. The contours of partisan affiliations within the mass public tell us much about the quality of democratic representation in the United States - whose voices are expressed, how these voices are expressed, which campaigns for office are successful, and ultimately what issues make it to a governing agenda. Unlike political parties in many other well-established democracies, the Democrats and Republicans have no formal admission records. For this reason, it has become standard practice when polling the electorate to inquire about partisan self-identifications. Indeed, no survey of political attitudes would be complete without instrumenta-

James A. McCann (mccannj@purdue.edu) is a professor of political science at Purdue University, West Lafayette, IN 47907. Katsuo A. Nishikawa Chávez (knishika@trinity.edu) is an associate professor of political science at Trinity University, San Antonio, TX 78212.

Support for conducting the surveys analyzed here was provided by the Russell Sage Foundation (grant \#88-08-19), the Carnegie Corporation of New York (grants D08079, D06079), the Center for Social Sciences at Purdue University, the Irma Rangel Public Policy Institute at the University of TexasAustin, and the Center for Comparative Immigration Studies at the University of California-San Diego. Much of this research was conducted when the first author was a Visiting Scholar at the Russell Sage Foundation. All original surveys analyzed in this article were authorized by the Purdue University Institutional Review Board. Data and supporting materials necessary to reproduce the numerical results in the paper are available in the JOP Dataverse (https://dataverse.harvard.edu/dataverse/jop). An online appendix with supplementary material is available at http://dx.doi.org/10.1086/686688.

The Journal of Politics, volume 78, number 4. Published online August 3, 2016. http://dx.doi.org/10.1086/686688

(c) 2016 by the Southern Political Science Association. All rights reserved. 0022-3816/2016/7804-0017\$10.00 
tion on partisanship, and the scholarly literature on party identification is perhaps the largest in the entire field of public opinion research.

Much less is known about the partisan inclinations of the foreign-born and how these attitudes compare to those of native-born Americans. The general consensus among scholars is that partisanship is relatively shallow within this population (Abrajano 2010; Abrajano and Alvarez 2010; Cain, Kiewiet, and Uhlaner 1991; Fraga et al. 2011; Hajnal and Lee 2011; Jones-Correa 1998; Junn et al. 2011; Lien, Conway, and Wong 2004; Nguyen and Garand 2009; Pantoja 2013; Schildkraut 2013; Wong 2006). As Schildkraut (2013, 29-30) writes, the incidence of party identification among immigrants today "is low, which is attributed to a variety of factors, including the lack of information about American partisan politics, the lack of outreach by parties, and that issues of central concern to immigrants might not align with the nation's current left/right divide."

Without denying the significance of these impediments, we offer a somewhat different perspective on partisan inclusion, one that situates party membership within the ebb and flow of electoral processes and uncovers a level of partisanship that had previously gone unnoticed. We focus in particular on Mexicans in the United States. Nearly onethird of the contemporary foreign-born population emigrated from Mexico, a percentage that far exceeds other nationality groups. It is therefore fitting when assessing trajectories of immigrant incorporation into American party politics to pay close attention to the Mexican community, though of course this limits our ability to generalize across the entire foreignborn population. Given that Mexicans lag behind other immigrant groups with respect to naturalization rates, educational attainment, and other indicators of social, economic, and civic integration, the Mexican-born could be considered a "hard case" for political inclusion (Perlmann 2005).

These background circumstances notwithstanding, analyses of original panel surveys of Mexican immigrants conducted over two recent election cycles (2006 and 2008) reveal that a considerable amount of partisan bonding takes place during major national campaigns. Election periods are moments of intense political conflict when invitations to "join the party" become ubiquitous (Brady, Johnston, and Sides 2006). The findings presented below indicate that Mexicans in the United States respond to these signals. Exposure to campaign invitations can have large and durable effects on partisan membership, with the Democratic Party being the main beneficiary. When gauging levels of partisan belonging among the foreign-born, political calendars matter. We also find evidence, however, of reliable negative partisanship. The Mexican immigrants in our study were reluctant to identify with the Republican Party even when exposed to political advertising that dramatically boosted ratings of the Republican standard-bearer John McCain. This mixture of dynamic "positive" partisanship with respect to one major party coupled with rather stable "negative" partisanship regarding the other stands in marked contrast to patterns of party identification that have long been recognized within the general American public.

\section{THEORETICAL BACKGROUND AND HYPOTHESES}

When asked whether they usually think of themselves as a Democrat, a Republican, an Independent, or something else, approximately two out of three citizens in recent decades have identified as partisans according to surveys conducted by the American National Election Study. Two theoretical conceptualizations have framed much of the research on these attitudes. The first, which dates to the seminal work of Campbell et al. (1960), draws from reference and small group theory: "The tie between individual and party is psychological - an extension of one's ego to include feeling a part of a group" (Miller and Shanks 1996, 120). Green, Palmquist, and Schickler (2002) offer a social identity theory of partisanship that builds on this premise. Recognizing that the Democrats and Republicans comprise many diverse groups that reflect the major divisions in society along ethnic, racial, occupational, gender, generational, and other lines, Green et al. posit that Americans implicitly ask themselves what groups come to mind when thinking about the two parties and which set of groups if any best describes them $(2002,8)$. Stereotypical understandings of partisan blocs combine with self-appraisal to foster identification as a party member.

An alternative conceptualization of partisanship highlights the instrumental goal-oriented nature of partisan affiliations; identification with a party implies preferences for particular government policies or resonance with certain ideological postures and core political values. This perspective is most closely associated with the work of Anthony Downs (1957). Such a view is not necessarily at odds with a social psychological characterization. In practice, there may be a good deal of overlap between the two. Recognition of oneself as a member of, say, an ethnic minority group could carry with it preferences for government actions that further the representation of the group. Consequently, social identities and group interests might jointly underlie partisan inclusion.

Although scholars vary in the theoretical conceptualization of partisanship, it is clear that the roots of partisan group membership extend to childhood socialization experiences (Jennings, Stoker, and Bowers 2009; Lewis-Beck et al. 2008; Miller and Shanks 1996; Wolak 2009). Social identities, personal values, and basic orientations toward party politics 
emerge well before one reaches voting age. The foundations that are established in these early years shape partisan attitudes over the life course, making party identification one of the most stable political dispositions for Americans. Campaigns and other major political events might make specific issues more prominent or bring to mind particular considerations about government officials and policies, which in turn could influence beliefs and feelings about the parties (Carsey and Layman 2006; Green et al. 2002). Yet absent a major restructuring of partisan coalitions, we would expect the distribution of partisanship within the mass public to be consistent over time.

For foreign-born residents of the United States, identifications with a party could be more fluid and tentative. The vast majority of immigrants in the country settled after their formative childhood years. Without an early familiarity with the American political system, immigrants are liable to approach party politics in the United States with a large amount of uncertainty (Abrajano 2010; Abrajano and Alvarez 2010; Hajnal and Lee 2011; Wals 2013; Wong et al. 2011). To be sure, various social identities and policy postures - the raw material for partisan affiliations - are evident for the foreignborn. In focus group discussions with migrants from Latin America, for example, Schildkraut (2013) reports that subjects were ever mindful of their shared identities as "newcomers" and "immigrants" who are distinctive in many ways compared to the dominant population. ${ }^{1}$ When commenting on public policy issues, they indicated that "it matters strongly whether the politicians they support pay attention to the needs and policy preferences of immigrants" (38). Schildkraut notes that the policies that came up were not only conventional ones (e.g., education, security, crime, or the economy) but also "immigrant-specific," such as criticism of harsh deportation measures taken by US authorities and the exploitation of immigrants in the workplace. Comparable "immigrant-specific" policy dispositions emerge as well in large- $N$ surveys of foreign-born Latinos (e.g., Branton 2007; Rousem, Wilkinson, and Garand 2010).

For many immigrants, whether and how these identities and preferences relate to partisan politics in the United States may be far from clear. The parties themselves add to these uncertainties by investing only modestly in direct personal outreach to the foreign-born (Bloemraad, Voss, and Lee 2011; Jones-Correa 1998; Wong 2006). In the last great wave of migrant settlement a century ago, local parties served as

1. Wong et al. (2011) find that Asian immigrants in the United States are similarly prone to adopt social identities related to their distinctive "foreign-born ethnic" background. leading agents of immigrant political incorporation (Silbey 2001). Today party organizations at this grassroots level are largely invisible to both the foreign-born and the nativeborn (Wong 2006). Partisan energies are instead concentrated on getting candidates elected, which means reaching out periodically during campaigns to their most reliable voters. Most immigrants currently living in the United States are not American citizens and would never be placed on contact lists for neighborhood partisan canvassers. Many of those who have become naturalized may not have a sufficiently lengthy voting history to attract the attention of party mobilizers. Given this lack of attention, Hajnal and Lee (2011) and Wong et al. (2011) view "nonpartisanship" as a rationally adaptive option for many of the foreign-born.

While the strategic environment surrounding party politics today no doubt hinders the emergence of partisan bonds among immigrants, relatively little is known about how the foreign-born react to the outreach efforts that the two parties do in fact undertake, namely, the robust dissemination of political messages during national campaign cycles. Short candidate-centered campaign commercials, photo-ops, and the like are invitations to join the political club. Even in an age when ads are microtargeted for narrow audiences, all immigrants are likely exposed to such messages (McCann and Jones-Correa 2016). Campaign outreach to Latinos in particular often advances two interrelated themes, which correspond to the two theoretical conceptualizations of partisanship that are prevalent in the scholarly literature - an appeal to general interests, that is, "join us because of the values, principles, and political goals we have in common," and an appeal to group belonging and solidarity, that is, "people like you are welcome here" (Abrajano 2010, 47-52; Connaughton 2005). Both types of messages could be compelling for immigrants, making the American party system more approachable. Since the 1990s, campaign organizations have made special efforts to reach out to foreign-born Latinos by airing increasing numbers of political ads in Spanish (Abrajano 2010; Barreto, Merolla, and DeFrancesco Soto 2011).

Although no previous research has examined how immigrant partisanship changes during major campaigns, Alvarez and García Bedolla (2003) report in a study of Latino voters (including both US-born Latinos and naturalized immigrants) that in comparison to Anglos, the partisan attitudes of Latinos are shaped to a greater extent by "political" forces. Other works have found that campaigns can have significant effects on Latino voter participation rates (e.g., Abrajano 2010: Barreto et al. 2011; DeFrancesco Soto and Merolla 2006; García Bedolla and Michelson 2012; Panagopoulos and Green 2010). In light of this literature, it is reasonable to assume that Latino immigrants are cognizant of election-year political conflict and out- 
reach. Our central hypothesis is that in such periods, they more readily affiliate with a party.

This expectation could imply that many of the foreignborn are open-minded "floating partisans" who move toward the Democrats or Republicans depending on the balance of partisan campaign messages that reach them in an election cycle. If this were the case, it would be difficult to argue that such individuals are emerging "partisans" in a truly meaningful sense. There are reasons to suspect, however, that immigrants do not "float" evenly between the two camps in response to campaign stimuli. Messages from Democratic candidates could make more of a difference, in that the foreign-born likely harbor greater uncertainty about their fit with the Democrats vis-à-vis Republicans. Even in an era of growing political polarization, the Democrats have been described as a relatively more moderate and heterogeneous "catch-all" party in comparison to the Republicans (Muirhead 2014, 11). This is especially true for issues related to cultural diversity and immigration. Within Congress, DW-NOMINATE scores indicate that the Republicans have moved further as a group to the right in these areas than the Democrats have to the left (D'Antonio, Tuch, and Baker 2013). These differences between the two partisan camps are evident as well in surveys of Republican and Democratic convention delegates and financial supporters (see figs. A1A3 in the appendix, available online).

Few of the Latino immigrants in our panel surveys would have been familiar with congressional voting records, and there would have been little to no direct contact with partisan elites. Nevertheless, government officials, convention delegates, and political contributors provide important cues about where the Democrats and Republicans stand on key policy debates, which groups are part of each coalition, and what it means to be a partisan (Carmines and Stimson 1989). The foreign-born would likely pick up on the rather clear and polarizing signals regarding immigration from Republican leaders and activists between election cycles. This could blunt the more positive messages of inclusion that Republican candidates disseminate during a campaign, given the salience of "immigrant-specific" policies within this population.

Another factor that could moderate the effects of campaigns on partisanship is an immigrant's pre-existing degree of incorporation into economic, social, cultural, civic, and political life in the United States. Prior research shows that the longer an immigrant has resided in the country, the higher the probability of identifying with a party. Those who possess more socioeconomic resources are more apt to be partisans, as are immigrants who have become naturalized citizens or are more interested in American politics (Cain et al. 1991; Hajnal and Lee 2011; Wong 2000; Wong et al.
2011). This previous work points to the possibility that immigrants who possess fewer resources, are less motivated to follow public affairs, or have resided in the United States for less time are especially moved by campaign invitations; the better resourced, the more highly engaged, and the more experienced may possess more stable partisan orientations.

Of course the absence of early childhood socialization into American politics may prevent the foreign-born from ever acquiring the kind of persistent attachments to a party that are characteristic of US-born Americans. Immigrants may never feel so "at home" in a political party that they are unmoved by campaigns. The hypothesis that election-year political outreach pulls immigrants toward the party systembut that this effect is more profound on the Democratic side and is especially strong for the less incorporated-is examined in the following section.

\section{RESEARCH DESIGN AND FINDINGS}

To estimate the impact of political campaigns on the partisan attachments of immigrants, we draw from panel surveys of the Mexican-born population in 2006 and 2008, where noncitizens as well as citizens were sampled. Panel surveys have long been recognized as essential for tracking campaign effects within the general electorate (Bartels 2006). To our knowledge, this is the first instance in which election-year panel studies have been used to trace the dynamics of political attitudes specifically among the foreign-born. ${ }^{2}$

\section{Study 1, the 2006 midterms}

In June of 2006, a relatively quiescent time in the midterm election cycle, telephone interviews were conducted with 753 Mexican immigrants across three sampling sites, Dallas, San Diego, and north-central Indiana, including Indianapolis but excluding the Chicago region. Respondents were recruited randomly through records obtained from a wellestablished marketing research firm specializing in the Latino

2. We are aware of only one other academically rigorous survey of the foreign-born conducted during a major national election cycle where respondents were interviewed more than once, the 2012 Latino Immigrant National Election Study (LINES). Approximately one-third of the 1,304 participants in this study were surveyed right before the elections that year and then immediately afterward, a design that is similar to the traditional "pre/post" framework of the American National Election Study. While the 2012 LINES is a uniquely valuable resource for investigating the political attitudes of immigrants at the height of a campaign season (McCann and Jones-Correa 2016), this framework does not permit the modeling of campaign effects over time, given that the pre- and post-election interviews were spaced quite closely together and very few of the survey items were repeated; respondents in this study reported their party identification only once. 
community. ${ }^{3}$ Immediately after the November elections, as many immigrants as possible were contacted for another interview $(N=264) .{ }^{4}$ The three sampling areas were selected to maximize variation in settlement areas and demographic profiles (King, Keohane, and Verba 1994). Dallas and San Diego are major traditional destinations for migrants, with a current combined Mexican-born population at the time of the survey of over one million. Immigrants in these locations do not need to go out of their way to find social services in Spanish, and Latinos occupy a variety of offices in local government. North-central Indiana is typical of "new" settlement destinations for Mexicans and other immigrant groups. Between 2000 and 2004, the number of Indiana-based Mexicans rose by approximately 60,000. Out of all metropolitan areas in the United States, Indianapolis had the fifth-highest rate of Latino population growth dur-

3. $N=350$ in Dallas, 125 in San Diego, and 277 in Indiana. Nearly all interviews were conducted in Spanish, and on average they lasted just over 20 minutes. Interviewing Services of America (Van Nuys, CA), a firm with a long track record of academic survey research on Latinos, administered the interviews. Since no ready-to-use listings of immigrants are available in the three regional sites, random samples of "Mexican heritage" households were obtained from Geoscape International (Miami, FL). Up to 15 attempts were made to reach a respondent. Because the telephone records contained both US-born Mexican-Americans and immigrants in unknown proportions, and many lines were out of service, there is no straightforward way to calculate a rate of response. If disconnected telephone lines, calls that were never answered, busy signals, and individuals who asked to be contacted again before interviewers could determine whether they fit the study profile are counted as "nonresponses" (per the AAPOR RR1 calculation), the estimated response rate is a rather low $11 \%$. However, if the response rate is defined as the ratio of completed interviews/attempted interviews of subjects known to fit the study protocol (i.e., RR5 in the AAPOR guide), this figure is dramatically higher at $89 \%$. Whatever the method for calculating response rates, it is worth noting that with respect to key background variables such as gender, age, level of education, church attendance, and language use at home, study participants are similar to the Mexican-born respondents in other large-scale surveys (e.g., Moreno 2005).

4. Near the end of the 753 interviews in June, respondents were asked if they would be willing to take part in another survey during the fall; 655 (or approximately 87\%) agreed to this, left their first name or nickname, and gave up to two telephone numbers where they could be called. In November, we were able to reach and interview 264 Mexicans for the second round. This represents a successful contact rate of $40 \%$, using a baseline of 668 potential interviewees, or a rate of $35 \%$ if the baseline is the original 753 who were queried about participating in a follow-up survey wave. The most common reason for a respondent to be dropped from the panel was a telephone line that was no longer in service. In cases where the line was still active and the respondent could be reached (with up to 15 attempts), nearly all (97\% participated in the survey. Panel attrition is not significantly related to partisanship or most of the socioeconomic and demographic variables (level of affluence, gender, level of education, language use, religious practice, or time spent in the United States). There is a small but statistically significant correlation between age and being included in the second survey wave. As in the first wave, nearly all interviews in November were conducted in Spanish, with each lasting approximately 16 minutes on average. ing this period (Sagamore Institute for Policy Research 2006). While the number of Mexicans now living in Indiana is much smaller than in California or Texas, this rapid expansion of immigrant communities was unprecedented in the state.

In each survey wave, the questionnaire contained instrumentation to gauge partisan group membership using the traditional "Michigan" root item, "Generally, when thinking about American politics, do you consider yourself a Democrat, a Republican, an Independent, or something else?" The distributions of party identification appear in table 1 . Patterns in June are in keeping with previous work that finds low levels of partisanship among the Latino foreign-born (Hajnal and Lee 2011; Wong 2006). The Mexicans in this study were generally reluctant at that point in the year to affiliate with either the Democrats or the Republicans; over three-fourths declined to identify personally as a partisan. ${ }^{5}$ Among those expressing some form of partisanship, there was no clear tilt toward one camp or the other.

In the November survey round, a very different distribution is apparent. The incidence of partisanship was noticeably higher at that time, and the breakdown clearly favored the Democrats, with a gain of 17 percentage points. ${ }^{6}$ The midterm campaigns appear to have pulled many toward the party. Of course a large number of immigrants in November remained outside a partisan fold. Nevertheless, this significant change in partisan affiliations over just a five-month period is impressive. $^{7}$

No equivalent swings in partisanship occurred among US-born Latinos during these midterm elections. This is evident in the percentages in the lower part of table 1. In June of 2006, the Pew Hispanic Center conducted a nationally representative telephone survey of Latinos, most of whom were

5. The distribution of partisanship in June for the 264 immigrants who were successfully contacted and interviewed again following the November elections is quite similar to that for all 743 respondents in this initial wave: $18 \%$ were Democrats, $8 \%$ were Republicans, and $74 \%$ were neither.

6. Statistical analysis of marginal homogeneity (the Stuart-Maxwell test) indicates that the distribution of partisan identification following the election was significantly different from that in the June wave $(p<.001)$.

7. It is worth noting that comparative evaluations of the two major parties followed a trajectory that was similar to party identification from June to November. In each survey wave, respondents evaluated the Democrats and Republicans on a 0-10-point scale ranging from "very bad" to "very good." In the June wave, $23 \%$ gave the Democrats higher ratings than the Republicans, 27\% evaluated the Republicans more highly, and half gave them the same score or did not rate one or both of the parties. In November, the number of respondents giving the Democrats a higher score rose considerably to $42 \%$, and only $18 \%$ at that time evaluated the Republicans more highly; the number that did not rate one party more favorably than the other dropped by 10 points. 
Table 1. Party Identification among Mexican Immigrants and US-Born Latinos: Pre-campaign and Campaign Period Comparisons, 2006

\begin{tabular}{|c|c|c|c|}
\hline & $\begin{array}{l}\text { June } \\
(\%)\end{array}$ & $\begin{array}{c}\text { October/November } \\
(\%)\end{array}$ & $\begin{array}{c}\text { Change in } \\
\text { Partisanship } \\
(\%)\end{array}$ \\
\hline \multicolumn{4}{|l|}{ Mexican immigrants: } \\
\hline Democrat & 14 & 31 & +17 \\
\hline Republican & 9 & 6 & -3 \\
\hline $\begin{array}{c}\text { Neither Democrat } \\
\text { nor Republican }\end{array}$ & 77 & 63 & \\
\hline Total & 100 & 100 & \\
\hline$N$ & 743 & 264 & \\
\hline \multicolumn{4}{|l|}{ US-born Latinos: } \\
\hline Democrat & 42 & 41 & -1 \\
\hline Republican & 22 & 27 & +5 \\
\hline $\begin{array}{c}\text { Neither Democrat } \\
\text { nor Republican }\end{array}$ & 36 & 33 & \\
\hline Total & 100 & 100 & \\
\hline$N$ & 575 & 3,588 & \\
\hline
\end{tabular}

Source. Authors' two-wave panel survey of Mexican immigrants administered by telephone and conducted in collaboration with Wayne Cornelius and David Leal; Pew Hispanic Center "2006 National Survey of Latinos" (http://www.pewhispanic.org/ 2006/07/13/2006-national-survey-of-latinos/), administered by telephone between June 5 and July 3, 2006; and "2006 Cooperative Congressional Election Study" (http://projects.iq.harvard.edu/cces /home), conducted via the Internet in October.

Note. Party identification was measured using versions of the traditional ANES wording, "Generally, when thinking about American politics, do you consider yourself a Democrat, a Republican, an Independent, or something else?" (Mexican immigrants); "In politics today, do you consider yourself a Republican, a Democrat, an Independent, or something else?" (US-born Latinos in June); and "Generally speaking, do you think of yourself as a Democrat, Republican, Independent, or [other: specify]?” (USborn Latinos in October). Nearly all interviews with Mexican immigrants were conducted in Spanish; US-born Latinos were interviewed in English.

born in the United States. The timing of this study coincided almost exactly with the first wave of the Mexican immigrant panel. Among the native-born Latinos in the Pew poll, $42 \%$ considered themselves Democrats, 22\% were Republicans, and 36\% did not affiliate with either party. Four months later, at the height of the midterm campaign season, the $2006 \mathrm{Co}$ operative Congressional Election Study was fielded via the Internet. In total, 3,588 US-born Latinos took part in this investigation. In spite of the difference in survey mode, the breakdown in partisanship is nearly identical to that in the Pew study. ${ }^{8}$ Identification with the Republican Party ex-

8. The Pew Hispanic Center allowed respondents to be surveyed in either English or Spanish. To make these percentages for partisanship panded, but only by a very narrow margin, and the percent affiliating with the Democrats dropped by one point. ${ }^{9}$

The fact that an appreciable number of Mexican immigrants moved toward the American party system in the fall of 2006, and that the Democratic Party was the beneficiary of this rise in partisanship, suggests that Republican invitations to "join the club" fell on deaf ears. Individual-level analysis supports this interpretation. As shown in a separate table in the appendix (table A1; tables A1-A5 are available online), more than one out of five immigrants changed from nonpartisanship to identification with a party, with nearly all joining the Democrats. Some Mexicans left the party system during this period, but movement toward a party was clearly the dominant pattern. Approximately half of the sample did not express a partisan affiliation in either survey wave, which speaks to the limits of partisan incorporation. Yet the finding that nearly $50 \%$ of the immigrants identified as a partisan at one or both periods indicates a relatively high incidence of membership. This is, after all, a subpopulation that has been described previously as largely outside the boundaries of American party politics. At the same time, there is evidence of a persistent disinclination to join the Republican Party. Only $4 \%$ of the sample moved from nonpartisanship to identification as a Republican. This change was more than matched by movement away from the party. Furthermore, the number of consistent Republicans was vanishingly low (1\%). These patterns are suggestive of well-established negative partisanship, as hypothesized above.

Panel survey findings from the American National Election Study (ANES) are also presented in table A1 to offer a point of contrast. Over the course of the 2006 campaigns, no panel surveys similar to the Mexican immigrant study were done within the wider American electorate. Data from the 2008 ANES consequently serve as a comparative bench-

among US-born Latinos comparable to those from the Cooperative Congressional Election Study, which was administered only in English, those few native-born Latinos in the Pew poll who were interviewed partly or entirely in Spanish were dropped.

9. The 2006 CCES included a post-election wave in November, and partisanship was gauged again at that time. This item is not useful for comparative purposes, however, since the instrumentation was different from that in the Pew Hispanic Center poll and the Mexican immigrant surveys. When reporting their partisanship in the November installment of the CCES, respondents were asked an abbreviated version of the traditional question, with only "Democrat," "Republican," and "Independent" allowed (i.e., the "something else" option was omitted). Moreover, the measurement of party identification at that time was not prefaced by the phrase "generally speaking," a notable departure from standard practice. The instrumentation in October, however, followed the conventional wording and so is used here. 
mark. The mobilization environment in a presidential election year is typically more intense compared to midterm campaigns, and political competition in the 2008 cycle was particularly contentious. In January of that year, the ANES fielded the first wave of a long-term Internet-based panel survey. Partisan identifications for US-born Latinos, African Americans, and whites between that point and the postelection period - a much longer timespan than that covered in the 2006 panel-were extremely stable. The partisan messages that filled the airwaves as the 2008 campaigns progressed did not affect partisan identities for the US-born. Unlike in the immigrant sample, the boundaries of partisanship were in place prior to the campaigns.

Did shifts in immigrant partisanship vary by levels of socioeconomic, cultural, and civic resources, or by levels of interest in US politics? As the political climate became richer with mobilization messages, the less-resourced and lessmotivated may have been especially prone to becoming a partisan. Such variation in effects is explored through multivariate analysis. Table 2 presents the results from a logistic regression model where the dependent variable is identification as a partisan in November. The predictors in this model capture the major dimensions of social, economic, and civic life that have been linked to the political incorporation of immigrants: place of residence; civic status; time spent in the United States; attention to US politics; level of formal education; gender; age; affluence, as indicated by an inventory of household amenities; language use at home; involvement in religious services; the number of close friends and family members who still resided in Mexico; and the frequency of sending funds back to Mexico. The latter two variables touch on whether interpersonal networks for respondents were

Table 2. Logistic Regression Model of Partisan Identification among Mexican Immigrants in November 2006

\begin{tabular}{lccc}
\hline & & & \\
& Coefficient $(b)$ & SE & Odds Ratio $\left(e^{b}\right)$ \\
\hline Identify with a party ${ }_{\text {June }} 2006$ & & & \\
Sampling location: & $1.38^{* *}$ & .33 & 3.97 \\
$\quad$ San Diego & -.28 & .42 & .76 \\
Indiana & .03 & .27 & 1.03 \\
Civic status: & & & \\
Noncitizen with papers & -.52 & .64 & .59 \\
Noncitizen without papers & -.69 & .67 & .50 \\
Personal background factor: & & & \\
Interest in US politics & .21 & .18 & 1.23 \\
Time in the United States (years) & .01 & .02 & 1.01 \\
Education level & .11 & .09 & 1.12 \\
Age (years) & -.01 & .02 & 1.00 \\
Gender (female) & -.41 & .33 & .67 \\
$\quad$ Household affluence & -.03 & .26 & .97 \\
Language use at home & .21 & .28 & 1.23 \\
Religious attendance & .05 & .13 & 1.05 \\
Transnational ties: & & & \\
$\quad$ Family and friends in Mexico & .15 & .17 & 1.16 \\
Send remittances & -.02 & .13 & .98 \\
Constant & -2.25 & 1.82 & .11 \\
\hline
\end{tabular}

Source. Authors' telephone panel surveys of Mexican immigrants.

Note. $N=753$; missing values were imputed via MI (chained equations), with 20 imputations. The dependent variable is coded 1 for respondents who identified with a party in the November wave, and 0 otherwise. Partisan identification in the June wave was dummy-coded $(1=$ identify as Democrat or Republican). See the appendix (table A5) for other item wordings and coding. Collinearity diagnostics indicate low variance inflation factors (VIF). The results for a comparable multinomial logistic regression model, where the dependent variable takes on three values (identify in November as a Democrat, as a Republican, or with neither party), are given in the appendix (table A2).

$+p<.10$.

${ }^{*} p<.05$. 
oriented toward the sending or receiving country. To control for the stability of partisanship, so that change in attitude from June to November is modeled, lagged values of the dependent variable are also included as predictors (Bartels 2006)..$^{10}$

Contrary to expectations, the coefficients in table 2 uncover little to no variation in campaign effects across subgroups. The only significant predictor is the lagged dependent variable $(p<.01)$. There is little evidence to support the notion that campaigns exert an especially strong pull on immigrants who lack the resources or interests that might otherwise propel them toward the party system. Even among well-established immigrants, political outreach can affect partisan connections. If the dependent variable is instead coded on a three-point categorical scale (Democrat, Republican, or nonpartisan) to take into account movement toward a specific party between June and November, comparable findings emerge (see table A2 in the appendix).

These analyses offer much evidence for the propositions that for Mexicans the boundaries of membership in the Democratic Party grow as campaigns proceed, that these immigrants are never so rooted that they are unresponsive to Democratic campaign signals, but that Republican messages are ineffective. However, while panel survey designs provide exceptional leverage for making such causal inferences, it is possible that differences in responsiveness to campaigns are instead due to variations in exposure to political signals in the first place. In the fall of 2006, Mexican immigrants might have seen and heard fewer Republican messages. Given this possibility, a second study was conducted to confirm the interpretations from the 2006 midterms.

\section{Study 2, the 2008 presidential election}

Tracing the impact of campaign communication is notoriously difficult because of measurement challenges. When asked how often they have seen or heard political commercials or received pamphlets from a campaign, many survey respondents simply cannot recall their exposure accurately (Ansolabehere, Iyengar, and Simon 1999). In the preceding analysis, we inferred that changes in partisanship among Mexicans between June and November of 2006 came about from reactions to campaign stimuli. This is a reasonable interpretation, but it would be more compelling to have direct and accurate measures of exposure to mobilization appeals.

10. When estimating this logistic regression model, missing values were multiply imputed via chained equations. Recent work by Peytchev (2012) suggests that multiple imputation is an effective way to correct for potential attrition biases in panel surveys and also obtain more efficient estimates.
For this reason, a randomized political advertising experiment was embedded in a second two-wave panel survey conducted during the 2008 presidential campaign.

As in 2006, randomly selected immigrants from Mexico were interviewed by telephone using a similar sampling frame, with similar rates of response. Nearly all surveys were again in Spanish. ${ }^{11}$ In total, 1,023 respondents took part in the first wave of the study, which commenced after the Labor Day weekend and continued through the month of September. Sampling this time was in two regions rather than three: north-central Indiana $(N=501)$, again excluding the Chicago area, and San Antonio, TX $(N=522)$. The reduction in survey sites raised the number of respondents in each area, which serves to increase the statistical power for regional and demographic comparisons. San Antonio was chosen in place of Dallas because its Mexican population is larger and somewhat better established. ${ }^{12}$ These features offer a more advantageous contrast with the emerging Mexican population of Indiana.

A few minutes into the first wave interview, respondents were randomly divided into three groups. Approximately half were chosen to listen over the telephone to a 60-second Spanish-language ad either for Barack Obama $(N=262)$ or John McCain $(N=250)$. These were actual ads produced for Latino radio stations. Each featured an enthusiastic endorsement from a member of the Latino community. In the Obama spot, the speaker was a youthful-sounding male with a middle-class Mexican accent. For the McCain ad, a former roommate of the nominee and native Spanish speaker was recruited for the part. The text of the two commercials is given in table A4. During major campaigns, short positive ads like these are ubiquitous on Spanish-language television and radio stations (Abrajano 2010). Although the focus was primarily on the individual nominees, a central theme in both advertisements was multicultural solidarity and shared interests within the partisan fold.

The goal in exposing respondents to an ad was to gauge more precisely than in 2006 how such campaign stimuli influence partisan affiliations and whether any effects persist until the end of the campaign. Subjects were told simply that researchers wished to know whether the ad in their opin-

11. The firm Interviewing Services of America again administered the interviews, with telephone numbers drawn from "Mexican heritage" households. The rate of completed interviews/attempted interviews for subjects found to fit the subject profile (RR5) was just over $90 \%$.

12. In the San Antonio sample, respondents had lived in the United States an average of 23 years, which is significantly longer than in either the Dallas or San Diego samples in 2006. Moreover, nearly half of the immigrants in San Antonio reported being naturalized US citizens, a proportion that is substantially higher than in the Indiana sample. 
ion gave a positive or negative impression of the candidate. (Not surprisingly, very few Mexicans in either treatment group believed that a negative impression was conveyed.) A third set of study participants $(N=511)$ served as the control group. ${ }^{13}$ Shortly after the 2008 elections, as many respondents as possible from both sampling locations were interviewed again (total $N=486$, a $48 \%$ recontact rate). ${ }^{14}$

One to two minutes after the ad exposure experiment in September, all respondents were asked to rate the major party presidential candidates using a 0 (very bad) to 10 (very good) scale. A three-point categorical measure was constructed from these evaluations: $(a)$ higher rating given to Obama; (b) higher rating for McCain; $(c)$ all other respondents. The distributions of these evaluations, broken down by experimental group, are given in table 3. Among subjects in the control group, the relative attractiveness of Barack Obama is apparent and not surprising (Bowler and Segura 2012). Over half viewed the Democratic nominee more positively than John McCain. One-third did not give either nominee a higher rating, and $12 \%$ had a relatively more favorable impression of McCain. Using these percentages as a baseline, it is clear that in the short-term, both ads were remarkably effective in molding opinions about the nominees. Listening to the McCain campaign ad boosted the candidate's standing by 22 percentage points. The Obama radio spot caused his relative favorability to rise 20 points, another very strong impact. Each of these effects is highly significant. Even though both candidates had been in the public eye for many months, neither was so well known that impressions had hardened. These results imply that Mexican immigrants, after only a slight amount of prompting, are fairly open to supporting Republican leaders.

Equally clear, however, is the reluctance to elevate assessments of the Republican Party. The McCain ad that car-

13. As a check on randomization procedures, bivariate correlations between all of the major demographic variables included in the questionnaire and assignment into one of the experimental groups were calculated. No significant correlations were found.

14. Approximately one-fifth of the respondents from September of 2008 dropped out of the post-election wave because they were no longer reachable at the telephone line that had been used just two months earlier. Another $26 \%$ of the first wave respondents apparently still used the same telephone number but could not be reached after more than 15 attempts. Only $3 \%$ of the survey participants in the first wave declined to take part in the second interview when successfully contacted again. Panel attrition was not significantly correlated with partisanship and most socioeconomic and demographic traits: gender, place of residence, level of affluence, citizenship and documentation status, education level, time spent in the United States, and language use at home. Nor was attrition correlated with the campaign advertising experimental treatments. As in 2006, however, there was a slight (and statistically significant) tendency for younger respondents from the first wave to drop out.
Table 3. Short-Term Impact of Campaign Ad Exposure on Relative Evaluations of the Presidential Candidates and Parties

\begin{tabular}{|c|c|c|c|}
\hline & \multirow{2}{*}{$\begin{array}{c}\text { No Ad } \\
\text { Exposure } \\
(\%)\end{array}$} & \multicolumn{2}{|c|}{$\begin{array}{l}\text { Randomized } \\
\text { Exposure } \\
\text { to an Ad } \\
(\%)\end{array}$} \\
\hline & & Obama & McCain \\
\hline \multicolumn{4}{|l|}{ Relative candidate evaluations: } \\
\hline Higher rating for Obama & 54 & 74 & 35 \\
\hline Higher rating for McCain & 12 & 4 & 34 \\
\hline $\begin{array}{l}\text { Neither rated higher than } \\
\text { the other }\end{array}$ & 34 & 22 & 31 \\
\hline Total & 100 & 100 & 100 \\
\hline Likelihood ratio test $\left(\chi_{2}^{2}\right)$ & & $34.1^{\star *}$ & $51.4^{* *}$ \\
\hline \multicolumn{4}{|l|}{ Relative partisan evaluations: } \\
\hline Higher rating for Democrats & 43 & 55 & 46 \\
\hline Higher rating for Republicans & 17 & 13 & 23 \\
\hline $\begin{array}{l}\text { Neither rated higher than } \\
\text { the other }\end{array}$ & 41 & 32 & 31 \\
\hline Total & 101 & 100 & 100 \\
\hline Likelihood ratio test $\left(\chi_{2}^{2}\right)$ & & $9.9^{* *}$ & $7.8^{*}$ \\
\hline
\end{tabular}

Source. Authors' telephone surveys of Mexican immigrants in San Antonio and Indiana, September 2008, conducted in collaboration with Stacey Connaughton.

Note. $N=1,023$ (262 in the Obama ad group, 250 in the McCain ad group, and 511 in the control group). Approximately one to two minutes after the administration of the advertising treatment, respondents evaluated the major parties and candidates using a scale from 0 (very bad) to 10 (very good). These scores were used to calculate relative candidate and partisan evaluations. The likelihood-ratio test indicates the statistical significance of differences in response proportions between an experimental treatment group and the control group.

${ }^{+} p<.10$.

${ }^{*} p<.05$.

${ }^{*} p<.01$.

ried so much punch when the presidential nominees were evaluated had a much more subdued effect on the relative appeal of Republicans as an organization. In fact, exposure to the commercial for McCain actually caused favorability ratings for both parties to jump slightly compared to the control group, 5 points in the case of Republicans and 3 for the Democrats. Listening to the Obama campaign commercial had a very different effect. In this instance, the increase in the relative favorability of Democrats is not as great as that for Obama himself, but it is nonetheless large-a 12 point gain ( $55 \%$ vs. $43 \%$ for immigrants in the control group). These findings lend strong support to the hypothe- 
sis that campaigns cultivate a sense of partisanship for this population but that minds are generally made up when considering the Republican Party.

Can listening to a brief political advertisement shape partisan identifications over the duration of the campaign? If so, this would help account for the rather large campaign effects observed in the 2006 midterms within an immigrant population that is not widely targeted by the parties; a modest amount of exposure to political messages may pay dividends over the long run. It would be unrealistic to expect respondents in either of the treatment groups to remember the contents of a commercial for very long. Few commit such minutia to long-term memory. Yet changes in the summary judgments immigrants make about the parties or about their own identities as partisans could persist weeks or months after exposure to an ad. Hill et al. (2013) posit that a particular persuasive message disseminated during a campaign could affect opinions weeks or months later if there are subsequent reinforcing stimuli in the political environment; "communication effects may be, and perhaps often are, held in place by a long-term flow of communication" (Hill et al. 2013, 523). After taking part in the first wave of the survey, respondents experienced another four to eight weeks of intense partisan conflict and mobilization. This is certainly the kind of environment that could have reinforced the changes in partisanship that were induced in September.

When contacted again after the election, the impact of exposure to the Obama ad was indeed reflected in the distribution of partisan identification (see table 4). For the control subjects at this time, $47 \%$ considered themselves Democrats, while only $7 \%$ were Republicans. Tellingly, among immigrants who were exposed to the Obama ad, the level of Democratic identification was considerably higher at $62 \%$. This is an extraordinary effect in light of the rather minor experimental intervention - exposure to a single short advertisement many weeks earlier. No comparable impact is seen within the McCain advertising group. This constitutes solid evidence for the hypothesis that the Mexican-born respond to campaign invitations but that there is much resistance to overtures from the Republican side.

Given that all of the immigrants in the panel would have been exposed to campaign advertisements and other political stimuli between September and November, the results from this experiment and those from study 1 suggest that affiliations with the Democratic Party, but not the Republicans, would have increased from one survey wave to the next even for respondents in the control group. This expectation is confirmed by comparing pre-treatment benchmark distributions of party identification from September to breakdowns of partisanship following the election (middle and bottom of table 4). Prior to the application of the treatments, $35 \%$ of the subjects who were randomly selected for the control group identified as Democrats. Among these respondents, the number of Democrats grew by 12 points come November. This increase is highly significant, as indicated by the Stuart-Maxwell chi-square test of change in proportions between two panel waves. For Mexicans in the McCain advertisement group, the gain in Democratic identification over this period is comparable to that for the control subjects and nearly matches the increase in Democratic affiliation over the course of the 2006 immigrant panel study (table 1). Respondents in the Obama treatment group evidenced a steeper rise in Democratic ties ( $+20 \%)$ owing to their greater exposure to mobilizing signals from that party. ${ }^{15}$

To assess subgroup variations in political advertising effects, party identifications gauged in November were regressed on the two experimental treatment indicators and the same resource and motivational items from the 2006 midterm panel: place of residence (San Antonio or north-central Indiana), civic status (citizen, noncitizen with papers, or undocumented), level of interest in American politics, time spent in the United States, education level, gender, household affluence, religious attendance, language use, the number of family and friends still residing in Mexico, and the frequency of sending remittances to that country; pre-treatment party identification and ideological positions (dummy variables indicating whether the respondent identified as being on the "left" or "right") were also included in the set of predictors. Multiplicative interaction terms were then added one at a time to the model to test whether the immigrants' prior levels of incorporation into American economic, social, culture, and civic life affect responsiveness to campaign signals. No noteworthy interactions surfaced. These findings are given in the appendix (table A3). As in the analysis from 2006, the immigrants in this sample responded to the ads in a generally uniform manner, connecting more closely to the Democratic Party while keeping their distance from the Republicans.

Before concluding, the causal mechanisms driving these connections may be explored by gauging changes in perceptions of the party system following exposure to the advertising treatments. We hypothesized that uncertainty about how the foreign-born fit into the Democratic coalition would keep many Mexican immigrants from identifying as members of that party, while somewhat more hardened doubts

15. The small and statistically insignificant likelihood-ratio $\chi^{2}$ values (2.1 and 2.4) reported for the distributions of pre-treatment partisanship in the "Obama Ad" and "McCain Ad" groups demonstrate that, in accordance with randomized assignment, placement in one of these groups was unrelated to pre-existing partisan affiliations. 
Table 4. Long-Term Impact of Campaign Ad Exposure in September of 2008 on Party Identification Following the November Election

\begin{tabular}{|c|c|c|c|}
\hline & \multirow{2}{*}{$\begin{array}{l}\text { No Ad Exposure } \\
(\%) \\
\text { Control Group }\end{array}$} & \multicolumn{2}{|c|}{$\begin{array}{l}\text { Randomized Exposure to an Ad } \\
\qquad(\%)\end{array}$} \\
\hline & & Obama & McCain \\
\hline \multicolumn{4}{|l|}{ Party identification, November: } \\
\hline Democrat & 47 & 62 & 52 \\
\hline Republican & 7 & 8 & 8 \\
\hline Neither Democrat nor Republican & 46 & 30 & 40 \\
\hline Total & 100 & 100 & 100 \\
\hline Likelihood ratio test $\left(\chi_{2}^{2}\right)$ & & $9.6^{* *}$ & 1.2 \\
\hline \multicolumn{4}{|l|}{ Longitudinal comparisons: } \\
\hline \multicolumn{4}{|c|}{ Party identification, September, pre-treatment: } \\
\hline Democrat & 35 & 42 & 39 \\
\hline Republican & 7 & 7 & 11 \\
\hline Neither Democrat nor Republican & 58 & 51 & 50 \\
\hline Total & 100 & 100 & 100 \\
\hline Likelihood ratio test $\left(\chi_{2}^{2}\right)$ & & 2.1 & 2.4 \\
\hline \multicolumn{4}{|c|}{ Change in partisan groupings, September to November: } \\
\hline Democrat & +12 & +20 & +13 \\
\hline Republican & No change & +1 & -3 \\
\hline Neither Democrat nor Republican & -12 & 21 & -10 \\
\hline Stuart-Maxwell $\chi_{2}^{2}$ & $12.41^{\star *}$ & $18.11^{* *}$ & $5.03^{+}$ \\
\hline
\end{tabular}

Source. Authors' telephone surveys of Mexican immigrants in San Antonio and Indiana, September and November 2008.

Note. $N=486$ (133 in the Obama ad group, 110 in the McCain ad group, and 243 in the control group); panel attrition between September and November is not significantly correlated with assignment to an experimental treatment group $\left(\chi_{2}^{2}=2.35 ; p=.31\right)$. The Stuart-Maxwell $\chi^{2}$ indicates the statistical significance of differences in response proportions between two panel survey waves for a given set of respondents.

${ }^{+} p<.10$.

${ }^{*} p<.05$.

${ }^{* *} p<.01$.

about fitting in with the Republicans would limit identification as a Republican. Campaign stimuli might be effective in counteracting the former impediment to partisanship but not the latter. Table 5 presents evidence in keeping with these dynamics. ${ }^{16}$

Near the end of the interview, respondents indicated how close they believed Barack Obama and John McCain were

16. Isolating causal mechanisms requires subjecting all potential mediating variables to independent randomized manipulations. Such a design is beyond the scope of the present study. As Green, Ha, and Bullock $(2010,202)$ note, "It may take decades to figure out the mechanisms that account for the causal relationships observed in social science." Additional longitudinal and experimental investigations of immigrant political attitudes in future campaign cycles are needed. In instances where there are many possible mediators and only one experimental intervention, researchers may not be able to pinpoint the exact causal pathways that transmit the effects of a treatment. Yet insights about causal sequences to the Mexican community and whether the Democratic and Republican parties represented "Latinos and Hispanics" and "immigrants." Personal impressions of Obama and McCain were combined to create a three-point comparative measure (Obama is closer to the Mexican community, McCain is closer, or neither is closer). In the control group, approximately half of the respondents saw no clear difference between the two nominees. Among those who saw a difference, Obama was viewed as closer by a three-to-one margin (36\% vs. 11\%). Exposure to the ad for McCain changed this margin significantly, increasing the number

may be gained by measuring several potential outcome variables. If certain outcomes are affected by the treatment as theorized, one can begin to build a persuasive case about the causal mechanisms underlying an effect. This is our aim in probing the impact of exposure to political advertisements on perceptions of the candidates and parties. 
Table 5. Impact of Campaign Ads on Impressions of the Candidates and Parties

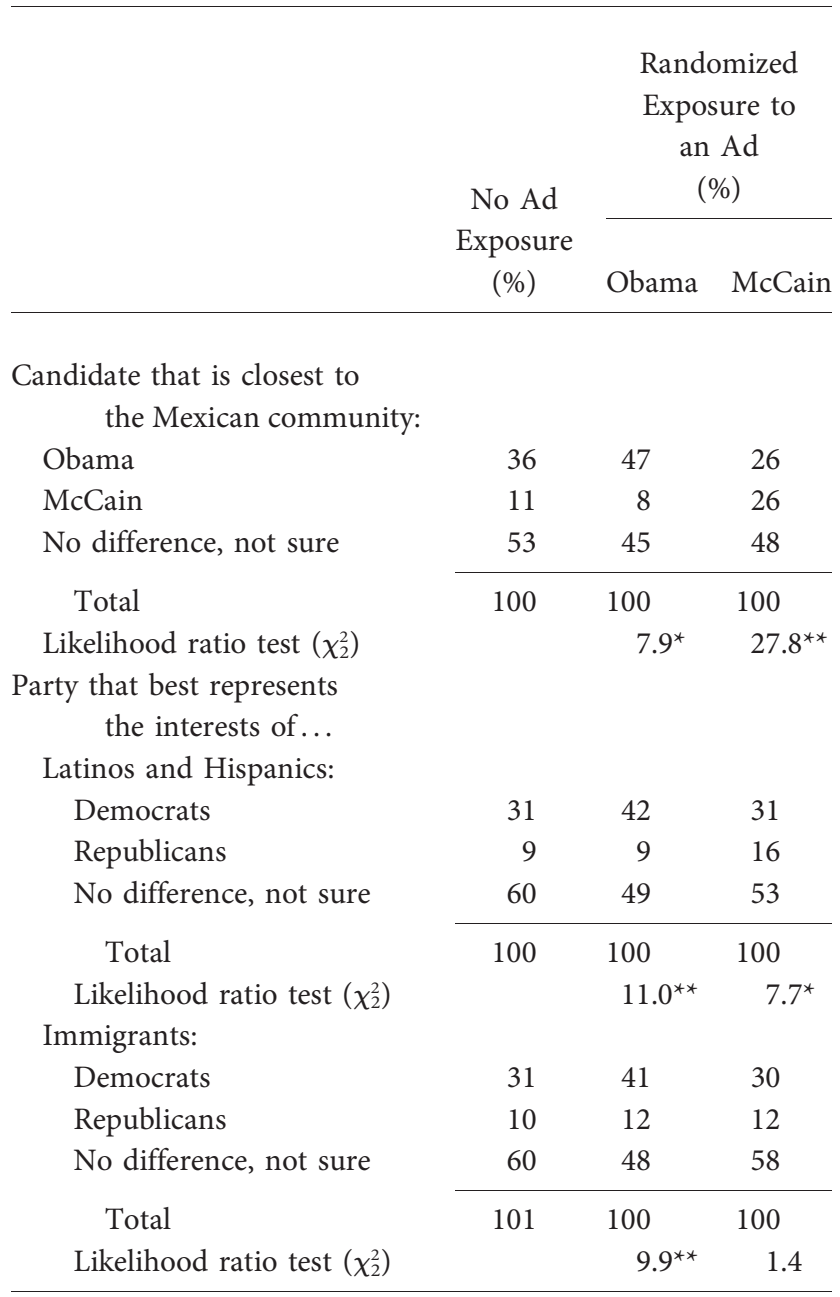

Note. Perceptions of the candidates' closeness to the Mexican community were measured following the experimental treatments in September through four-point scales ( $1=$ not at all close, $4=$ very close). These responses were used to calculate relative assessments. Perceptions of comparative partisan representativeness were gauged shortly thereafter through items asking the extent to which the [Democratic/Republican] Party represents the interests of [Latinos and Hispanics/Immigrants]. Spanish-language wordings are given in the appendix (table A5).

$+p<.10$.

${ }^{*} p<.05$.

${ }^{* *} p<.01$

believing that McCain was closer by 15 points relative to the control group. Immigrants who heard the commercial for Obama came away with a much better impression of the Democratic nominee, with a swing in percentages that was similar to that for the McCain advertisement group. These dynamics provide at least a partial explanation of what drove the changes in overall candidate attractiveness that were reported in table 3. The campaign spots for Obama and McCain were effective because they linked a candidate to a primary social identity group for respondents.
For subjects in the Obama advertisement treatment group, the positive effects of the commercial extended to judgments about the Democratic Party. Compared to the control group, immigrants hearing the ad for Obama were decidedly more inclined to see the Democrats as more accommodating of "Latinos and Hispanics" and "immigrants" ( $p<.01$ for both items). Exposure to the McCain campaign spot had a much weaker impact, particularly for beliefs about the representation of the foreign-born within the Republican Party. These findings help to flesh out the causal mechanisms behind the shifts in immigrant partisanship. Invitations from Democrats mattered in fostering affiliations with the party because they repositioned the Democratic Party in the eyes of respondents as comparatively more representative than the Republicans of their core identity groups. The McCain ad powerfully affected perceptions of the candidate himself, but beliefs about the Republican Party were relatively well crystallized.

\section{CONCLUSION}

Mexican immigrants are not as far removed from party politics in the United States as prior research has suggested. The surveys from which earlier works on immigrant partisanship have drawn are one-shot cross-sectional studies administered for the most part outside of an electoral context. The American party system on the other hand is inherently dynamic. Political parties do not hibernate in between election cycles, but from the perspective of the mass public, their organizational activities in these periods are all but invisible. During major national elections, the two parties collaborate with their chosen nominees to get out their messages and get out the vote. Immigrants, especially immigrants without voting rights, would not be the most attractive targets of mobilization. Even so, invitations to join the party are ever present. Partisan mobilization in elections, as Schattschneider (1975) emphasized, is contagious and hard to contain. Regardless of one's station in life, one cannot help but be exposed to Democratic and Republican overtures.

Longitudinal analyses from the 2006 and 2008 campaign cycles call attention to three notable features of contemporary Mexican immigrant partisanship. First, mobilization signals are highly consequential for self-described party membership. Many Mexicans join the party in the heat of the campaign. This mode of democratic expression is quite distinctive in comparison to US-born Americans, whose partisan ties tend to be consistent before and after campaigns. A second key lesson is that immigrants from Mexico who are well resourced and well established in the United States respond to campaign invitations to the same significant degree as those who are less incorporated. This implies that the 
Mexican-born on the whole - and perhaps the foreign-born population in general - may never be fully and unceasingly integrated into a political party. Such a finding underscores the paramount importance of early childhood political socialization in tying Americans reliably to a major party (Miller and Shanks 1996).

Finally, the survey results demonstrate persistent "negative partisanship" with respect to the Republicans, a disposition that is understandable given the political positioning of that party over the last two decades. When gauging partisan identities within any population, such negative dispositions are as worthy of exploration as positive ones (Campbell et al. 1960; Medeiros and Noel 2014; Rose and Mishler 1998). Knowing where you do not belong can be a relevant and meaningful anchor in political affairs (Hajnal and Lee 2011; Wong et al. 2011). Yet if partisanship within the Mexicanborn community were largely or exclusively "negative," troubling normative implications could be raised. For the general public, affirming positive connections to a major party can orient individuals toward the political system in a constructive manner, provide a basis for interpreting policy issues and evaluating government performance, and offer a framework for collective political action (Green et al. 2002; Huddy, Mason, and Aaroe 2015; Lewis-Beck et al. 2008; Muirhead 2014; Rosenblum 2008). The noteworthy rise of positive partisanship for Mexican immigrants during major national campaign cycles can thus be taken as a welcome harbinger of democratic inclusion (Lewis-Beck and Stegmaier 2016; Rosenblum and Tivig 2014; Sears, Danbold, and Zavala 2016).

The two electoral settings under scrutiny here, one a midterm contest and the other an open presidential race, were distinctive in many ways. The fact that each featured a substantial increase in attachments to the Democratic Party among Mexican immigrants points to a general recurring pattern of campaign effects. Such a generalization, however, should come with a slight caveat. For various reasons the political environments in 2006 and 2008 tended to favor the Democrats. With respect to the Mexican population in particular, the immigrant rights protests that took place in the spring of 2006 could have led many of the foreign-born to be especially open to mobilization signals from the Democratic Party during the fall campaign season. ${ }^{17} \mathrm{Had}$ panel surveys

17. These protests were staged in response to HR 4437, a bill from the Republican-controlled US House of Representatives that would have applied severe criminal penalties to the undocumented and those who assist them (Voss and Bloemraad 2011). Democrats were mindful of the campaign mobilization opportunities that HR 4437 presented. In the closing days of the 2006 elections, for example, Senate Minority Leader Harry Reid appeared on the Mexican American-oriented television network Azteca América. "Voting gives you a voice in affordable housing. Voting also been conducted in political climates that were less favorable toward that party, such as the 2010 or 2014 midterms, we would still expect to find similar gains in Democratic identifications over the course of the campaign, though perhaps with effects being more muted. Barring a major shift in the dispositions of Republican lawmakers and party activists towards identities and issues that Mexicans and other immigrant groups hold dear, a shift that appears improbable at this juncture, there is likely little chance that Republican campaign messages in any electoral environment could pull the Mexican-born toward that party, even if Republican candidates themselves are perceived as personally attractive figures. These conjectures highlight the need for further longitudinal research on political attitudes and socialization among immigrants, so that patterns of change and stability may be assessed both within and across diverse electoral cycles.

\section{ACKNOWLEDGMENTS}

We wish to thank Walt Stone, Jennifer Merolla, Ann Marie Clark, Ron Rapoport, Sue Stokes, Phil Cook, Elizabeth Cohen, Susan Silbey, Michael Jones-Correa, Jose Kaire, Eliza Osorio, Aaron Hoffman, Lonna Atkeson, Zuzana Ringlerova, Rune Slothuus, Stacey Connaughton, Sheldon Danziger, Aixa CintrónVélez, Michael Lewis-Beck, Steve Finkel, Heath Brown, Ran Hassin, Alex Todorov, Bob Bartlett, Federico Subervi, and the JOP anonymous reviewers for helpful feedback. Previous versions of this article were presented at the 2014 meeting of the American Political Science Association in Washington, DC, and in colloquia at the University of Pittsburgh, the University of Vermont, the CUNY Graduate Center, and the Russell Sage Foundation.

\section{REFERENCES}

Abrajano, Marisa A. 2010. Campaigning to the New American Electorate: Advertising to Latino Voters. Palo Alto, CA: Stanford University Press. Abrajano, Marisa A., and R. Michael Alvarez. 2010. New Faces, New Voices: The Hispanic Electorate in America. Princeton, NJ: Princeton University Press.

Alvarez, R. Michael, and Lisa García Bedolla. 2003. “The Foundations of Latino Voter Partisanship.” Lournal of Politics 65 (1): 31-49.

Ansolabehere, Stephen, Shanto Iyengar, and Adam Simon. 1999. "Replicating Experiments Using Aggregate and Survey Data: The Case of Negative Advertising and Turnout." American Political Science Review 93:901-9.

Barreto, Matt A. 2005. "Latino Immigrants at the Polls: Foreign-Born Voter Turnout in the 2002 Election." Political Research Quarterly 58 (1): 79-86.

gives you a voice in immigration," remarked the Democratic senator as part of the network's public service initiative "Tu Voto Cuenta/Your Vote Counts" (Martinez 2007). 
Barreto, Matt A., Jennifer Merolla, and Victoria DeFrancesco Soto. 2011. "Multiple Dimensions of Mobilization: The Effect of Direct Contact and Political Ads on Latino Turnout in the 2000 Presidential Election." Journal of Political Marketing 10 (4): 302-27.

Bartels, Larry M. 2006. "Three Virtues of Panel Data for the Analysis of Campaign Effects." In Henry Brady and Richard Johnston, eds., Capturing Campaign Effects. Ann Arbor: University of Michigan Press.

Bloemraad, Irene, Kim Voss, and Taeku Lee. 2011. "The Protests of 2006." In Kim Voss and Irene Bloemraad, eds., Rallying for Immigrant Rights. Berkeley: University of California Press.

Bowler, Shaun, and Gary M. Segura. 2012. The Future Is Ours: Minority Politics, Political Behavior, and the Multiracial Era of American Politics. Washington, DC: CQ.

Brady, Henry E., Richard Johnston, and John Sides. 2006. "The Study of Political Campaigns. In Henry E. Brady and Richard Johnston, eds., Capturing Campaign Effects. Ann Arbor: University of Michigan Press.

Branton, Regina. 2007. "Latino Attitudes toward Various Areas of Public Policy: The Importance of Acculturation." Political Research Quarterly 60 (2): 293-303.

Cain, Bruce E., D. Roderick Kiewiet, and Carole J. Uhlaner. 1991. "The Acquisition of Partisanship by Latinos and Asian Americans." American Journal of Political Science 35:390-422.

Campbell, Angus, Philip E. Converse, Warren Miller, and Donald Stokes. 1960. The American Voter. New York: Wiley.

Carmines, Edward G., and James A. Stimson. 1989. Issue Evolution: Race and the Transformation of American Politics. Princeton, NJ: Princeton University Press.

Carsey, Thomas, and Geoffrey C. Layman. 2006. "Changing Sides or Changing Minds? Party Identification and Policy Preferences in the American Electorate." American Journal of Political Science 50 (2): 464 77.

Connaughton, Stacey L. 2005. Inviting Latino Voters: Party Messages and Latino Party Identification. New York: Routledge.

D’Antonio, William, Steven A. Tuch, and Josiah R. Baker. 2013. Religion, Politics, and Polarization. New York: Routledge.

DeFrancesco Soto, Victoria M., and Jennifer L. Merolla. 2006. "Vota por tu Futuro: Partisan Mobilization of Latino Voters in the 2000 Presidential Election." Political Behavior 28:285-304

Downs, Anthony. 1957. An Economic Theory of Democracy. New York: Harper.

Fraga, Luis, John Garcia, Rodney Hero, and Michael Jones-Correa. 2011 Latinos in the New Millennium. New York: Cambridge University Press.

García Bedolla, Lisa, and Melissa R. Michelson. 2012. Mobilizing Inclusion. New Haven, CT: Yale University Press.

Green, Donald P., Chang E. Ha, and John G. Bullock. 2010. "Enough Already about 'Black Box' Experiments: Studying Mediation Is More Difficult than Most Scholars Suppose." ANNALS of the American Academy of Political and Social Science 628:200-208.

Green, Donald P., Bradley Palmquist, and Eric Schickler. 2002. Partisan Hearts and Minds. New Haven, CT: Yale University Press.

Hajnal, Zoltan, and Taeku Lee. 2011. Why Americans Don't Join the Party. Princeton, NJ: Princeton University Press.

Hill, Seth J., James Lo, Lynn Vavreck, and John Zaller. 2013. "How Quickly We Forget: The Duration of Persuasion Effects from Mass Communication." Political Communication 30 (4): 521-47.

Huddy, Leonie, Lilliana Mason, and Lene Aaroe. 2015. "Expressive Partisanship: Campaign Involvement, Political Emotion, and Partisan Identity." American Political Science Review 109 (1): 1-17.

Jennings, M. Kent, Laura Stoker, and Jake Bowers. 2009. "Politics across Generations." Journal of Politics 71 (3): 782-99.
Jones-Correa, Michael. 1998. Between Two Nations. Ithaca, NY: Cornell University Press.

Junn, Jane, Taeku Lee, S. Karthick Ramakrishnan, and Janelle Wong. 2011. "Asian American Public Opinion." In Robert Y. Shapiro and Lawrence R. Jacobs, eds., Oxford Handbook of the Presidency and the Media. New York: Oxford University Press.

Kam, Cindy D., Elizabeth Zechmeister, and Jennifer R. Wilking. 2008. "From the Gap to the Chasm: Gender and Participation among NonHispanic Whites and Mexican-Americans." Political Research Quarterly 61 (2): 205-18.

King, Gary, Robert Keohane, and Sidney Verba. 1994. Designing Social Inquiry. Princeton, NJ: Princeton University Press.

Lewis-Beck, Michael, William G. Jacoby, Helmut Norpoth, and Herbert F. Weisberg. 2008. The American Voter Revisited. Ann Arbor: University of Michigan Press.

Lewis-Beck, Michael, and Marty Stegmaier. 2016. “The Hispanic Immigrant Voter and the Classic American Voter." RSF: The Russell Sage Foundation Journal of the Social Sciences 2 (3): 165-81.

Lien, Pei-te, M. Margaret Conway, and Janelle Wong. 2004. The Politics of Asian Americans. New York: Routledge.

Martinez, Laura. 2007. "How Spanish-Language Media Lend Clout to the Hispanic Vote.” Advertising Age. http://adage.com/ (accessed February 5,2016$)$.

McCann, James A., and Michael Jones-Correa. 2016. "In the Public but Not the Electorate: The 'Civic Status Gap' in the United States.” RSF: The Russell Sage Foundation Journal of the Social Sciences 2 (3): 1-19.

Medeiros, Mike, and Alain Noel. 2014. "The Forgotten Side of Partisanship: Negative Party Identification in Four Anglo-American Democracies." Comparative Political Studies 47 (7): 1022-46.

Miller, Warren E., and J. Merrill Shanks. 1996. The New American Voter. Cambridge, MA: Harvard University Press.

Moreno, Alejandro. 2005. Nuestros Valores. Mexico City: Banamex.

Muirhead, Russell. 2014. The Promise of Party in a Polarized Age. Cambridge, MA: Harvard University Press.

Nguyen, N. Kim, and James C. Garand. 2009. "Partisan Strength and Nonpartisanship among Asian Americans.” American Politics Research 37 (3): 375-408.

Panagopoulos, Costas, and Donald P. Green. 2010. "Spanish-Language Radio Advertisements and Latino Voter Turnout in the 2006 Congressional Elections: Field Experimental Evidence." Political Research Quarterly 64 (3): 588-99.

Pantoja, Adrian D. 2013. "Latino Non-citizens Are neither Democrats nor Republicans." Latino Decisions. http://www.latinodecisions.com/blog/2013 /07/11/latino-non-citizens-are-neither-democrats-nor-republicans/ (accessed October 10, 2015).

Pantoja, Adrian D., Ricardo Ramirez, and Gary Segura. 2001. "Citizens by Choice, Voters by Necessity.” Political Research Quarterly 54 (4): 729 50.

Perlmann, Joel. 2005. Italians Then, Mexicans Now. New York: Russell Sage.

Peytchev, Andy. 2012. "Multiple Imputation for Unit Nonresponse and Measurement Error." Public Opinion Quarterly 76 (2): 214-37.

Ramakrishnan, S. Karthick. 2005. Democracy in Immigrant America. Palo Alto, CA: Stanford University Press.

Rose, Richard, and William Mishler. 1998. "Negative and Positive Party Identification in Post-Communist Countries." Electoral Studies 17 (2): 217-34.

Rosenblum, Nancy L. 2008. On the Side of the Angels. Princeton, NJ: Princeton University Press.

Rosenblum, Nancy L., and Andrea Tivig. 2014. "Political Incorporation in America: Immigrant Partisans.” Citizenship Studies 18 (2): 125-40. 
Rouse, Stella M., Betina Cutaia Wilkinson, and James C. Garand. 2010. "Divided Loyalties? Understanding Variation in Latino Attitudes toward Immigration.” Social Science Quarterly 91 (3): 856-82.

Sagamore Institute for Policy Research. 2006. "Connecting Mexico and the Hoosier Heartland: Policy Briefing.” http://www.sipr.org (accessed October 10, 2015).

Schattschneider, E. E. 1975. The Semisovereign People. New York: Dryden.

Schildkraut, Deborah J. 2013. "The Complicated Constituency: A Study of Immigrant Opinions about Political Representation.” Politics, Groups, and Identities 1 (1): 26-47.

Sears, David O., Felix Danbold, and Vanessa Zavala. 2016. "Incorporation of Latino Immigrants into the American Party System.” RSF The Russell Sage Foundation Journal of the Social Sciences 2 (1): 183204.

Silbey, Joel H. 2001. “'To One or Another of These Parties Every Many Belongs': The American Political Experience from Andrew Jackson to the Civil War." In Byron E. Shafer and Anthony J. Badger, eds., Con- testing Democracy: Substance and Structure in American Political History, 1775-2000. Lawrence: University Press of Kansas.

Verba, Sidney, Kay Lehman Schlozman, and Henry E. Brady. 1995. Voice and Equality: Civic Voluntarism in American Politics. Cambridge, MA: Harvard University Press.

Voss, Kim, and Irene Bloemraad. 2011. Rallying for Immigrant Rights. Berkeley: University of California Press.

Wals, Sergio. 2013. "Made in the USA? Immigrants' Imported Ideology and Political Engagement." Electoral Studies 32 (4): 756-67.

Wolak, Jennifer. 2009. "Explaining Change in Party Identification in Adolescence." Electoral Studies 28:573-83.

Wong, Janelle S. 2000. "The Effects of Age and Political Exposure on the Development of Party Identification among Asian American and Latino Immigrants in the United States." Political Behavior 22 (4): 341-71.

Wong, Janelle S. 2006. Democracy's Promise: Immigrants and American Civic Institutions. Ann Arbor: University of Michigan Press.

Wong, Janelle S., S. Karthick Ramakrishnan, Taeku Lee, and Jane Junn. 2011. Asian American Political Participation. New York: Russell Sage. 